Claremont Colleges

Scholarship@ Claremont

Pomona Faculty Publications and Research

Pomona Faculty Scholarship

$1-1-2014$

\title{
Reviving the Reluctant Art of Iranian Dance in Iran and in the American Diaspora
}

Anthony Shay

Pomona College

\section{Recommended Citation}

Shay, Anthony. "Reviving the Reluctant Art of Iranian Dance in Iran and in the American Diaspora." In Juniper Hill and Caroline Bithel, Eds., The Oxford Handbook of Music Revival. New York: Oxford University Press, 2014, 618-643.

This Book Chapter is brought to you for free and open access by the Pomona Faculty Scholarship at Scholarship @ Claremont. It has been accepted for inclusion in Pomona Faculty Publications and Research by an authorized administrator of Scholarship @ Claremont. For more information, please contact scholarship@cuc.claremont.edu. 


\title{
CHAPTER 28
}

\section{REVIVING THE RELUCTANT ART OF IRANIAN DANCE IN IRAN AND IN THE AMERICAN DIASPORA}

\author{
ANTHONY SHAY
}

IN this chapter, I look at the various ways in which different individuals-Iranians, Iranian immigrants in the West, Americans, and other non-Iranians-participated in several revival Iranian dance movements, beginning in the 1930 s and continuing into the twenty-first century. The new interest in dance that began in this period coincided with a period of incipient modernity and its need to find ways in which to construct a modern national identity. As increasing numbers of Iranians made their way to the West, first as students and ultimately as immigrants and refugees, they discovered that dance as a representational field dovetailed with their need to forge an ethnic identity as Iranians both inside and outside of Iran. Dance, which once constituted a scandal when performed in public, became a new, often glamorous vehicle with which to burnish Iranian identities to new publics.

I open the chapter by discussing the problematic terms "revival" and "revivalist" and by explaining the theoretical and conceptual frameworks I employ to frame my topic. I then provide a brief overview of the historical and cultural context for traditional dance forms in Iran before moving on to describe the creation of new hybrid forms in early twentieth-century Iran and dance performances in both Iran and the diaspora. Finally, I describe and analyze the three broad modes of revivalist dance creation and performance throughout the twentieth and twenty-first centuries. 


\section{What IS REVIVAL DANCE IN AN IRANIAN CONTEXT?}

I characterize the use of the term "revival dance" in the context of this chapter as "unfortunate" because the stagings of Iranian dance that occur in the diaspora, and those which occurred before the 1979 Islamic Revolution in Iran itself, are not, strictly speaking, revivals of a tradition. The traditions themselves are very much alive. Peasants and tribesmen continue to perform their dances, and urban Iranians perform solo improvised dance both in Iran (albeit clandestinely) and in the diaspora, as evidenced by internet videos on YouTube. Thus, the use of the term "revivalist" addresses the performers of those choreographic forms that are derived from the bricolage of regional folk dances, solo improvised dance performed in social gatherings, the movements of former professional dancers, and Western ballet. The dances performed in public contexts, often labeled Persian classical or folk dance, such as those seen in dance concerts and festival settings in Europe and the United States, are often individual creations and constitute, in Hobsbawm and Ranger's (1983) terms, "invented traditions."

Only half of the population of Iran can be considered Persian, if by "Persian" we mean an individual whose mother tongue is Persian (Farsi). There exists no dance that is specific only to that ethnolinguistic group. Although a Persian classical music tradition exists for which the vocal portions are sung in Persian, no analogous classical dance tradition exists (see Ameri 2003).

The term "revival" is saturated with too many meanings and contexts, most of which may seem inappropriate to the phenomena that many scholars characterize with this term. Basically, the term "revivalist" dancer or musician, as used especially by folklorists and ethnomusicologists, refers to any outsider performing music or dances not of their own culture; that is, someone who is not a native performer to the tradition. In other words, it is a euphemism used to refer to performances and individuals that the speaker considers "impure" and inauthentic.

Most individuals, including many scholars outside of folklore and ethnomusicology, understand the meaning of "revival" in either of two ways. First, they may understand the term "revival" as it is used to describe movements like the great "religious revival" that occurred in the United States in the nineteenth century. Or, second, they may understand "revival" as it is used in the arts and popular culture: for example, "reviving" a work by Vivaldi that has fallen out of the repertoire or staging a "revival" of The Sound of Music. These acts revive a work that has laid dormant for a period, and, usually, an attempt is made either to perform the work in the same way that it was performed earlier or else to stage a modern reinterpretation of the work. However, in the parlance of folklorists and ethnomusicologists, the term "revivalist" applies to "individuals who celebrated traditions not their own" (Jackson 1993: 73). Furthermore, in matters of public funding for folk and traditional dance and music (in the United States, at least), the 
presence of revivalist performers constitutes grounds for denying funding to these performers who are not of "pure blood." (See Nooshin, chapter 13 in this volume.)

The discourse among folklorists and ethnomusicologists, although moderating recently and consequently growing less strident (Rosenberg 1993), almost always involves issues of ethnicity, authenticity, romanticism, and appropriation. Having lived a life as a "revivalist" - that is, as a professional choreographer and dancer performing, for more than fifty years, dances that are not native to my Anglo-American backgroundI know from personal experience that this label- "revivalist"-is not a neutral one. It is often accompanied by a smug expression of superiority from many purist folklorists and ethnomusicologists who seem to have forgotten that they often came to their chosen field through their own revivalist performances. Ethnomusicologist Jeff Todd Titon, who has served as a panelist on the National Endowment for the Arts Folk Arts panel, stated: "Folk Arts did not fund revivalists. Some panel members felt that the presence of revivalists tainted the project" (1992: 220). Titon found it ironic that, while serving as a panelist, he often worked with "mostly lapsed revivalists" (1992: 222).

Folklorist Barbara Kirshenblatt-Gimblett writes even more forcefully in describing the funding of folk artists, their participation in folk festivals, and the rejection of revivalist artists:

Underlying much celebratory diversity is an affirmative racialism coded in the terms of culture. It reveals itself in the privileging of origins... and authenticity, especially when linked to primordial claims.

(Kirshenblatt-Gimblett 1994: 236-237)

This "racialism" results, as Kirshenblatt-Gimblett indicates, in separating the pure from the impure: "Quivering with issues of authenticity and iconicity, these events tend to make a clear distinction between doers and watchers. Mainstream Americans are the designated watchers and 'ethnics' and 'natives' are the doers" (1991: 424).

Yet another notion of "revival" is bound up in the idea that any dance or genre of music that is performed outside of its original context of village or tribal wedding or celebration, even if by native performers, becomes "revivalistic" because of the alterations required by a specific performance. And although many revivalist individuals have, not infrequently, developed an original and professional level of artistry within a tradition in which they were not born but in which they have participated for most of their lives, there is the suggestion that they can never achieve what a native performer can.

The term "revivalist," then, covers far too much scholarly territory. I write here as an unreconstructed and unrepentant revivalist artist, and I combine these different understandings of "revival" for the purposes of this chapter.

If we understand the phenomenon of revival dance traditions as being those performances that anyone other than a native to a particular tradition in his or her own normal cultural context performs, we can see that several layers exist. In this tradition, I would include those Iranian peasants and tribesmen performing regional folk dances in festival settings (in which the context is significantly altered from the normal circumstances 
in which they spontaneously perform their native dances), as well as dancers in the professional urban genres of so-called Persian classical dance. Thus, "revival" Iranian dance in its presentational form constitutes several layers; here, I use the term "revival dance" to refer to dance performances that occur in any decontextualized context outside of dance in the field.

I identify three periods in which these revivalist presentational styles may be seen to fall: (1) the beginnings of the so-called national dance style from the late $1920 \mathrm{~s}$ until the late 1950s, (2) the state folk dance ensemble model period of 1958-1990, and (3) what I call the "new vision" period (a term I borrow from Iranian choreographer Jamal) that began in the 199os. It is important to stress that not only do the three periods overlap but that all three styles continue as modes of presentation into the twenty-first century.

\section{Theories, Concepts, ANd Viewpoints}

To analyze and describe revivalist Iranian dance, I use five conceptual approaches. First, anthropologist David M. Guss, following Richard Handler (1988), provides a concept of "cultural objectification," one of the results of which I use to illuminate aspects of the staged dance productions analyzed in this chapter:

The aesthetic makeover required in order to translate these forms into national spectacles shares many features cross-culturally. The privileging of the visual, accomplished through colorful costumes and dramatic choreography, combines with technical excellence and virtuosity to present a cheerful, unceasingly optimistic world. This increased theatricalization abjures any mention of true historical conditions and replaces them with the staged creation of a mythic detemporalized past.

(Guss 2000: 14)

Here, Guss encapsulates the way in which technical aspects of staged performances-of all three styles but especially the first two-produce the kind of choreographic and staging strategies used in the production of Iranian dance by revival performers and choreographers, both Iranian and non-Iranian, to achieve the effects and results described.

Second, Jane C. Desmond offers insight into the crucial way in which dance and other movement systems not only reflect but are constitutive of ethnicity and identity:

So ubiquitous, so "naturalized" as to be nearly unnoticed as a symbolic system, movement is a primary not secondary social "text".... Its articulation signals group affiliation and group differences. Movement serves as a marker for the production of gender, racial, ethnic, class, and national identities. 
The Iranian government during the Pahlavi years grasped this concept and used dance as a vehicle to construct Iranian national identity and to cultivate nationalist emotions (Meftahi 2007).

Third, because Iranians regard the public performance of dance, historically associated with prostitution and homosexuality, with considerable ambiguity, I utilize my concept of "choreophobia" from an earlier study (Shay 1999) to theorize how Iranians and others turned to dance as a means of creating a vehicle of cultural representation. I show how choreophobia haunts these performances (Shay 1999: 1, 123-150). Thus, I refer to dance as the "reluctant art" because many Iranians regard it in a negative light and do not consider it as proper behavior, much less an art form.

Fourth, I use the concept of "parallel traditions" that I developed in an earlier study (Shay 2002a). Because there are multiple ways in which Iranian dance is presented in a staged fashion, it is necessary to separate the threads of this intricate garment to see its cultural, aesthetic, and social structure. We may distinguish, then, dances performed by villagers and tribal people in the Iranian world (what Theresa J. Buckland [1999] has termed "dance in the field") from a wide variety of other manifestations, including performances by tribal groups on public stages in Tehran and regional cities; performances by Armenian Iranians who began teaching dance in Western-style classes and recitals; so-called national dance performances or stagings created for the former Pahlavi state-supported national dance companies (the Mahalli Dancers and National Folklore Organization); performances by Iranian students in the United States and other countries; performances in tourist settings; performances for weddings and other celebratory occasions in the Iranian diaspora; and performances by non-Iranians of various Iranian dance genres. These constitute only a suggestive list of possible layers.

In the past, many scholars have been reluctant to engage with anything but "authentic" dance in the field, regarding all else as "fakelore." Dance ethnographers Georgiana Gore and Maria Koutsouba encapsulate this attitude: "Any representation of traditional dance outside its customary context is not more than 'imitation' and may be seen as an artificial and adulterated version of the 'original' " (1992: 104). To fruitfully analyze and theorize dance contexts, apart from dance in the field, I created the concept of parallel traditions (Shay 2002a) to avoid invidious comparisons between the various layers and without making elaborate scholarly excuses to undertake the study of different dance genres. As artificial, slick, or cheesy as some of these layers may appear, each is worthy of study because each layer contains social and political messages regarding ethnicity, class, and gender, and each raises deeply complex issues of authenticity, appropriation, and ownership. In addition, the individuals who spend hours perfecting their performances generally believe deeply in the choreographic activities in which they participate and thus endow these performances with a kind of authenticity.

Fifth, and finally, I utilize Edward Said's (1978) concept of orientalism From the outset of the creation of a new Iranian dance genre (Iran's "national dance"), the term "orientalism" was most often used as a synonym for "character dance" in the classical ballet classes in which it was taught and performed from the late 1920s. Orientalist images flooded those performances and still characterize many contemporary performances (Shay 
1999: 156-170). Character or national dances combined classical ballet vocabulary with elements of folk or urban dances of a particular country, and they were popular because they responded to the nationalism that was spreading throughout Central and Eastern Europe during the second half of the nineteenth century to the first half of the twentieth century. The degree to which actual folk and urban elements are utilized alongside classical Western ballet vocabulary varies a great deal in individual performances and choreographies. Because most choreographers, Iranian and non-Iranian, claim that their work is authentic and true to the dances in the field, it is important that we look briefly at dance in the field. First, however, I will contextualize these parallel traditions by providing historical and cultural background for the changing uses, meanings, and practices of Iranian dance.

\section{Historical AND CUltural BaCkground}

The dance traditions found in Iran reflect its ethnic diversity. These dances are also found in neighboring jurisdictions such as Iraqi and Turkish Kurdistan, the Republic of Azerbaijan, Afghanistan, Turkmenia, Pakistan, Tajikistan, and Uzbekistan, which together form a larger Iranian world in cultural and historical terms, sometimes referred to as the "Persianate." There are two major choreographic traditions in Iran: solo improvised dance, which is associated primarily with urban areas but is also found in specific movement traditions in rural districts, and regional folk dances, which are largely group dances, although they may occasionally be performed as solos and which are stylistically specific to certain ethnic groups or geographic areas.

Historically, Iran has had a long history of multiethnic, multilingual, and religious diversity, and many of the populations, such as the Arabs, Kurds, Baluchis, Turkmen, and Azerbaijanis of Iran, constitute parts of ethnic and linguistic groups that extend well beyond the political borders of the contemporary Iranian state into neighboring states.

Iranians lived under three different regimes during the twentieth century: the Qajar dynasty (1785-1925), the Pahlavi regime (1925-1979), and the Islamic Republic (1980- ). Each of these regimes held a different stance toward the phenomena of both professional and private dance performances.

During the Qajar period, dancing boys and women constituted part of professional entertainment groups known as motrebs. These were large and small groups, urban-based and ambulatory. The companies during this period were frequently all male or all female. Motrebs played music, danced, and acted, among other performance expressions. To this day, the word motreb constitutes an insult to performers, especially serious musicians. Most individuals in Iranian society regarded public dancers of both sexes as prostitutes, and these performers occupied the lowest possible social rung. Nevertheless, their performances permeated all classes of society, including the court, and their presence was regarded as de rigueur for major celebrations and happy occasions, such as weddings. In addition, dance constituted an important aspect of urban women's social lives, in which they danced, acted, and sang theatrical playlets to 
entertain themselves in the privacy of the women's quarters, well into the Pahlavi period ('Enjavi-Shirazi 1972; Shay 1995b, 1999).

The two Pahlavi sovereignties, but especially that of Mohammad Reza Shah Pahlavi, turned to a new dance genre-(mis)named "national dance"-that was practiced throughout the 1930 s and beyond and that served, alongside regional folk dances performed in concert format, to build a sense of Iranian nationalism among the multiethnic population and to represent Iran culturally at international events such as world fairs and concert tours (Meftahi 2007).

One of the first acts of the Islamic Republic was to prohibit dance in all forms, although the ban on folk dance was later lifted. Dancing professionally ended, and, even into the new millennium, dancing solo improvised dance in private carried the potential for harsh punishment if discovered. Because of the ban, which continues into the twenty-first century, I argue that solo improvised dance now constitutes a form of resistance to the Islamic regime because many Iranians continue to dance in secret, as well as to use solo improvised dance as a means of taunting the regime in public spaces (Mahdavi 2009; Shay 1999, 2008b).

\section{DANCE IN IRAN}

If one thinks of folklore as denoting "expressive forms, processes, and behaviors (1) that we customarily learn, teach, and utilize or display during face-to-face interactions, and (2) that we judge to be traditional" (Georges and Jones 1995: 1), then both of these choreographic traditions, regional folk dances and urban solo improvised dance, must be considered as forms of folklore since they are both "traditional" and overwhelmingly learned in "face-to-face interactions" rather than in formal educational settings, although diasporic Iranians attend classes in growing numbers to learn to dance.

\section{Regional Folk Dances}

Throughout Iran, dancing constitutes an appropriate form of expression for celebratory events such as weddings and, less often, circumcision ceremonies. Dance is never a part of religious observances, a point that cannot be overemphasized in an Islamic context. This is a crucial observation because many of the Shi'ia religious rites are characterized by specific movement systems that must not, in an Islamic context, be confused with dance (Shay 1995a, 1999). In rural areas, regional folk dances, which are frequently performed in large groups, are generally performed out of doors due to the small size of houses (see Figure 28.1). For full descriptions of regional folk dances, see Hamada (1978), Hasanov (1988), Shay (2002b), and Shay and Sellers-Young (2005: 5). ${ }^{1}$

In addition to celebratory occasions, during the Pahlavi period, young dancers in Bojnurd, a town in Eastern Iran, also formed amateur performance groups that 


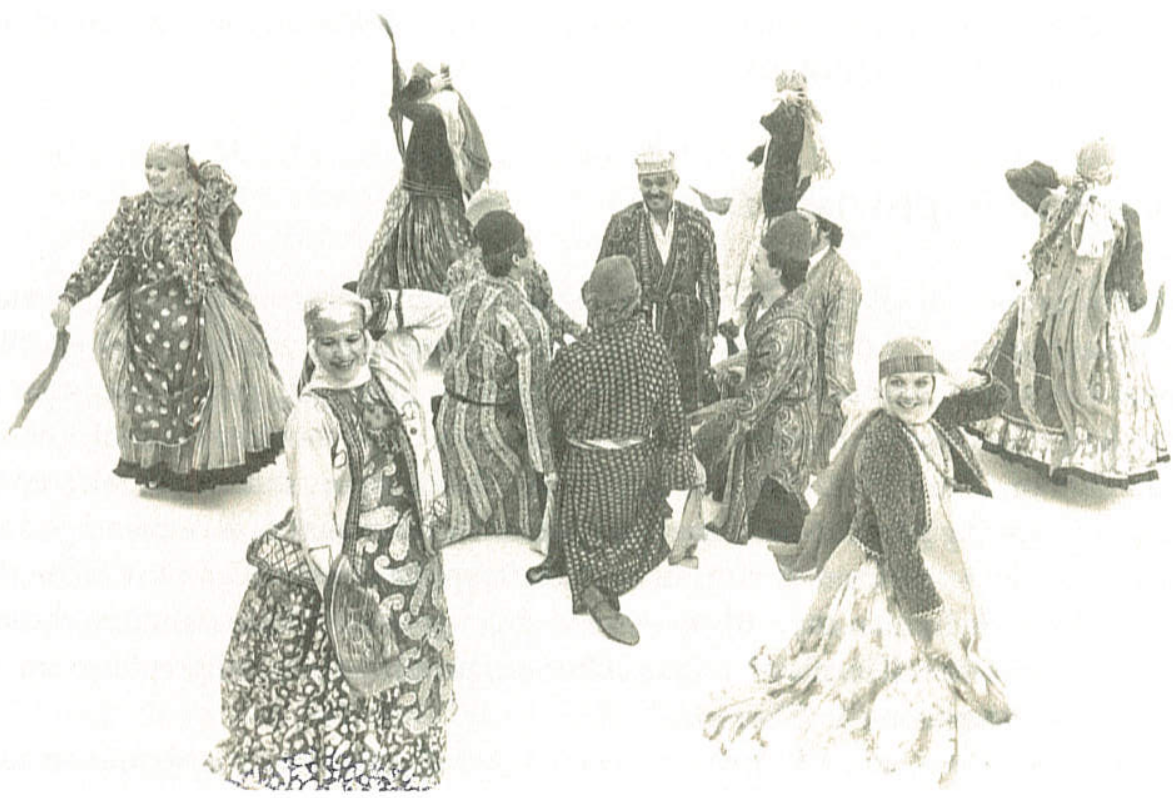

FIGURE 28.1 "Raqs-E Chupi" Qashqa'i folk dance. Choreographed by Anthony Shay. Photo by Darren Young, Los Angeles, 1978. Courtesy of the AVAZ International Dance Theatre.

appeared on national holidays or other special occasions. These dancers only performed the dances of their region and specific ethnic group. As is common in the more familiar festival circuits of Eastern Europe, the dancers would arrange the order and length of the dances and rehearse them for festival appearances in front of audiences in a formal setting, but they did not choreograph the dances in the manner of state-supported professional folk dance ensembles, a practice that thus constitutes a separate parallel tradition (Hamada 1978: 58).

I saw village groups that appeared in a series of exhibitions held at the Golestan Palace in Tehran during the Pahlavi era, in which the arts and crafts-including dancing and music - and folk arts of the various provinces were displayed to introduce the capital's population to the expressive cultures of the villages and tribes of Iran. In addition, variety television shows, like those hosted by Feridun Farrokhzad and Parviz Gharib-Afshar, also frequently hosted performances by rural dancers. These performances also constitute a parallel tradition because, although the peasants and tribesmen who appeared in these performances were the authentic inhabitants of their respective areas, performing their own dances, the circumstances were very different: They rehearsed for these performances rather than performing spontaneously, the performances were timed, they were oriented toward an audience, the performance space was restricted, the dancers were all young, and they used the finest dancers of their respective regions. Thus, these performances were already removed from dance in the field in a number of ways that constitute a different parallel layer. And, although these performances are certainly 
closer to dance in the field than a performance by a state-supported ensemble, they are, nevertheless, qualitatively distinct.

\section{Urban Solo Improvised Dance}

Although examples of solo improvised dancing abound in rural areas such as the Persian Gulf, tribal regions, and the Caspian Sea provinces, these dance genres exhibit specific regional styles, with emphasis placed on the repetition of specific movements such as the twirling of kerchiefs in the dances of Fars or the pelvic and shoulder shimmies of the Persian Gulf or Gilan. The urban solo improvised dance genre, sometimes referred to as majlesi (meaning party or social gathering, after its most common venue of performance) in its domestic form, derives its aesthetic impulses from different sources: the visual world of the Iranian city with its rich images of geometric forms, and improvisation, which underlies all forms of Iranian cultural expression from calligraphy to storytelling, architecture to music (Shay 1999).

Like the visual arts, dance is linked to geometry and is, in fact, an embodied manifestation of the geometry found in the calligraphy, architecture, and architectural decoration that permeate urban life (Hill and Grabar 1964; Pope 1964-1965a,b; Shay 1997). Like theater and music, as well as the visual arts, as shown by Gülru Necipoglu's magisterial study (1995) of architectural scrolls (tumar), improvisation is a key element in the production of dance as well as calligraphy, architecture, Islamic decoration, and music. All of these forms, visual and performing arts, depend on the learning and assimilating of brief choreographic, visual, or musical motifs; the artist then combines and recombines these elements to create new and fresh compositions-architectural, decorative, musical, or choreographic. Hill and Grabar propose that " $[\mathrm{t}]$ he more significant facts about the geometric units used seem ... to be first, their constant mobility in time and space" (1964: 80-81). It is this flowing movement that characterizes all of the arts, and above all it is embodied in solo improvised dance. This element of improvisation maintains the freshness of expression in the most gifted performers. (For descriptions of solo improvised dance, see Ameri 2003 and Shay 1999.)

\section{Choreophobic Environment}

Historically, throughout the Middle East, both male and female professional dancer-entertainers plied their trade in large urban centers and as itinerant performers. As was the case for most public entertainers, their mode of expression was nearly always associated with prostitution by the population at large. This choreophobic attitude continued unabated into the twenty-first century (Shay 1999). The following observation, made a century ago by the Qajar princess Taj Al-Saltana (died 1937) in her diaries, sums 
up most Iranians' attitudes toward public dancers, even today, when such performances are banned:

That night 'Abdi Jan's troupe had been called so that the harem occupants could watch the show. Of course, you remember 'Abdi well. Let me, nonetheless, give you a description of his looks. He was a lad of about twelve or thirteen, with large, black eyes, languid and incredibly beautiful and attractive. His face was tanned and good-looking, his lips crimson, and his hair black and thick. Renowned throughout the town, the boy had a thousand adoring lovers. Being a dancer, however, he was unworthy of being anyone's beloved.

(Al-Saltana 1993: 163)

Theater historian Bahram Beiza'i notes that dance constituted the basis of traditional comic theater, a frequently highly ribald form of entertainment (1965: 169). In this context, the dances were basically highly elaborate, virtuosic, and athletic versions of the domestic form of solo improvised dance. These athletic feats are depicted in paintings of the Qajar period (Falk 1972; Diba and Ekhtiar 1998). With the lack of royal and aristocratic support after the beginning of the Pahlavi era, this dance tradition faded away, and the new forms of professional dance, the so-called national dance, no longer featured the daring virtuosic feats of the finest dancers of the old traditional style.

Although traditional motrebi music and dance (named for the traditional entertainer, the motreb) persisted in the more traditional parts of Tehran, the loss of its former patronage doomed it to a slow death. The advent of the Islamic Revolution (1979) caused its final demise because of clerical hostility toward these forms of entertainment. Both Imam Khomeini and Ayyatollah Khamene'i pronounced in their fatwas that "Motreb music is illicit" (Fatemi 2005: 19). All dancing in public ceased, and the government attempted to ferret out parties in which solo improvised dance occurred, meting out severe punishment to those it caught (Mahdavi 2009; Shay 2008b).

\section{The BeginNing of ReVival Iranian DANCE: "NATIONAL DANCE"}

After the beginning of the Pahlavi era (1925-1979), the government and educated elites increasingly ignored traditional dance and theater, turning instead to Western forms such as classical ballet, which represented the modernity they craved. The first teachers and choreographers of ballet performances based on Iranian themes or featuring performances in which Iranian traditional movements were mixed with elements of ballet, were Armenians who immigrated to Iran. Prominent among these were Madame Yelena, Madame Cornelli, and Sarkis Djanbazian, all of whom had been trained in Russian ballet before coming to Iran. The introduction of Western 
forms of music and dance resulted in a division between the northern, more Westernized half of Tehran and the southern, more traditional and conservative areas of the city. This division continues today (see Mahdavi 2009). New contexts, such as proscenium arch theaters, began to appear to provide space for Westernized choreographic forms, whereas, in the southern districts, traditional performers continued to perform in traditional settings, for example, on planks thrown over a garden fountain ( $r u$-howz), a stage that constituted one of the most common performance sites for traditional dance and music. Traditional theater ( $r u$-howzi), which included dance and music, took its name from this practice. (See especially Fatemi's 2005 study.)

From the beginning, the newly established Armenian teachers created a new hybrid choreographic form in which ballet was combined with traditional Iranian movements and other choreographic elements-a form that would later be referred to in Iran as "national dance." As Meftahi describes it, "[Following] the popular concept of 'national dance' in Europe [the Armenian choreographers, and later the American Nilla Cram Cook] adapted some movements from Iranian dance in their performances and re-crafted their own classical dances with Iranian movements" (Meftahi 2007: 149). Although some individuals or companies performed en pointe, most performed Iranian character or national dance in bare feet or with special slippers or character shoes.

Knowing that they inhabited a choreophobic environment, the early choreographers chose to link their productions with poetry and bucolic or historical themes as a means of gaining support and cultural legitimacy among the more liberal and better-educated elements of the population. They did this by using images well known from Persian poetry, such as those of the rose and the nightingale, by turning to heroic, pre-Islamic themes as found in old Persian mythological sources such as the Shahnameh, or by choosing "innocent" themes from an idealized peasant life in which happy villagers go to the well for water or dance after a harvest. Such strategies recall Guss's concept of cultural objectification. Nesta Ramazani, a dancer in these early ballet productions, states: "I moved easily from performing a Zoroastrian temple dance to interpreting mystical Sufi poetry and to portraying the love of a rose and a nightingale" $(2002 \mathrm{xv})$. She observed of one of the first dances she performed in the role of a village girl:

Through pantomime we conveyed such activities as sifting flour, kneading bread, washing clothes, and playfully splashing each other with water. Our work finished, we beautified ourselves, preening while coquettishly swinging one hip. Picking up our chiffon handkerchiefs, we coyly twirled them overhead or from side to side, occasionally flipping them into the air, while spinning rapidly around and around. Unlike the dress of real village girls, our bodices were brief, revealing a bare midriff, and garnished with baubles and bangles that glinted in the stage lights.

(Ramazani 2002:5) 
Elsewhere she writes: "My longings and desires found expression through music and dance based largely on Western fantasy images of the East, images reinforced by my dance teacher, Mme. Cornelli, in whose choreography the Orient was represented as a magical land filled with flimsily clad dancing girls" (Ramazani 2002: 75). Thus, these dance performances embodied the essence of Said's notion of orientalism as well as Guss's concept of cultural objectification-the choreographic depiction of a dream-like world in which fantasy images of great luxury, sensuality, and an ahistorical Orient served to create a nostalgic never-never land past and a fantasy present. Such choreographic images continue to be popular in the Iranian diaspora, where, for example, in 1997, thousands of Iranian Americans flocked to the Orange County, California autumn Mehregan Festival to watch local community members dressed (in incorrectly rendered Sasanian clothing) as the "Iranian royal family" view a series of imagined dances, including those of a group of scantily clad, modern cabaret belly dancers.

Ramazani frequently refers to the choreophobic atmosphere in which she first performed: "For me, it was a simple matter: Dancing filled me with joy. For Tehran society, however it was scandalous. Good girls did not perform in public, baring their legs for all to see, putting themselves in the limelight to attract the lust of strangers" (2002: 1). This is a theme that Ramazani frequently reiterates throughout her narrative. And, indeed, in the beginning, due to this corrosive atmosphere, most of the performances were invitation-only, private recitals held in ballet studios rather than in public concert spaces.

In 1946, American Nilla Cram Cook founded a group that was supported by the Iranian government and toured several neighboring countries from 1947 to 1953 (Kiann 2000; Ramazani 2002). Cram Cook became an influential figure in the Iranian Ministry of Culture and served as a censor of Iranian theaters and cinema (Ramazani 2002: 171). Although her dance group performed the newly created genre, which mixed ballet with traditional movements, Cram Cook represented herself as reviving old historic traditions (Ramazani 2002: 76, 147, 170, 172-174), naming her dance program "The Revival of Ancient Iranian Arts" (Kiann 2000).

As part of an attempt to legitimate dance, Medjid Rezvani, one of the earliest revivalist performers active in Paris from the 1930s, wrote a history of dance aiming to prove the existence of a "classical" Iranian dance tradition complete with formal rules of performance and training (see especially 1962: 150-159). He concluded that "they are guarded, right up to our own times, the rules of the classical dance, even if a few old dancers are the only repositories of them" (Rezvani 1962: 159). Rezvani's fantasy of a classical dance tradition using codified movements (which he invented for his book, together with names for some eight steps and movements in the style of Western ballet) has been effectively shattered by 'Ameri's study (2003). In effect, Rezvani attempted to create an ancient history for a recently created dance genre.

In 1954, the Iranian Ministry of Culture and Arts opened the National Academy of Ballet with its performing arm, the Iranian National Ballet. For this project, the ministry 
brought in several American and British teachers, such as Ninette de Valois, who continued the practice of creating ballets with Iranian themes drawn from poetry and history. In this way, traditional music and dance genres that were mixed with Western elements found official government patronage and new performance venues such as radio and later television, as well as newly constructed concert halls and theaters.

In 1958, the Iranian government established a state folk dance ensemble, the Iran National Folklore Organization, under the direction of Nejad Ahmadzadeh. In the late 1960s, Robert de Warren, an English ballet dancer and choreographer, was invited to direct a similar group, the Mahalli Dancers, again using this style of mixed Iranian and Western elements. The companies performed staged versions of both solo improvised dance and regional folk dances based on historical and poetic themes.

In 1966, Abdollah Nazemi, who trained in the National Academy of Ballet and danced for several years with the National Iranian Ballet, formed his own company, the Pars National Ballet, which was associated with National Iranian Radio and Television. According to his printed program, the company's repertoire consisted of an eclectic mix of staged folk dances, Persian poetry and historically themed ballet, conventional Western classical ballet works, and modern works with both Western and Iranian musical scores. After the Revolution, Nazemi founded a group of the same name, but greatly reduced in size and scope, in southern California.

Thus, in these early performances, the use of Orientalist motifs, costumes, and staging strategies somewhat mitigated the choreophobic atmosphere, at least for the more Westernized Iranians. Nevertheless, choreophobia never disappeared, in spite of later Pahlavi government efforts to use dance as a means of constructing a national identity, as Jane C. Desmond has suggested. One of the first acts of Ayyatollah Khomeini in the Islamic Revolution (1979) was to ban all public performances of dance.

\section{Revival Dance in the Diaspora}

It is important to emphasize that most individuals who see Iranian folk dancing, including both Iranian city dwellers and foreigners, view it in the context of performances by the professional and semiprofessional dance ensembles found in pre-Revolution Iran and in the diaspora, rather than in the context of the village. In other words, they are exposed only to revival dance traditions. This style of choreography is still found in dance performances in which, as Guss describes in his concept of cultural objectification, a fantasy world of nostalgia is created. The multitude of displaced Iranians crave this choreographic nostalgia that revival dance provides.

Of the few Iranians who lived in the West before 1979, the vast majority were students and more than $90 \%$ were male (Shay 1999). A few Iranian and non-Iranian 


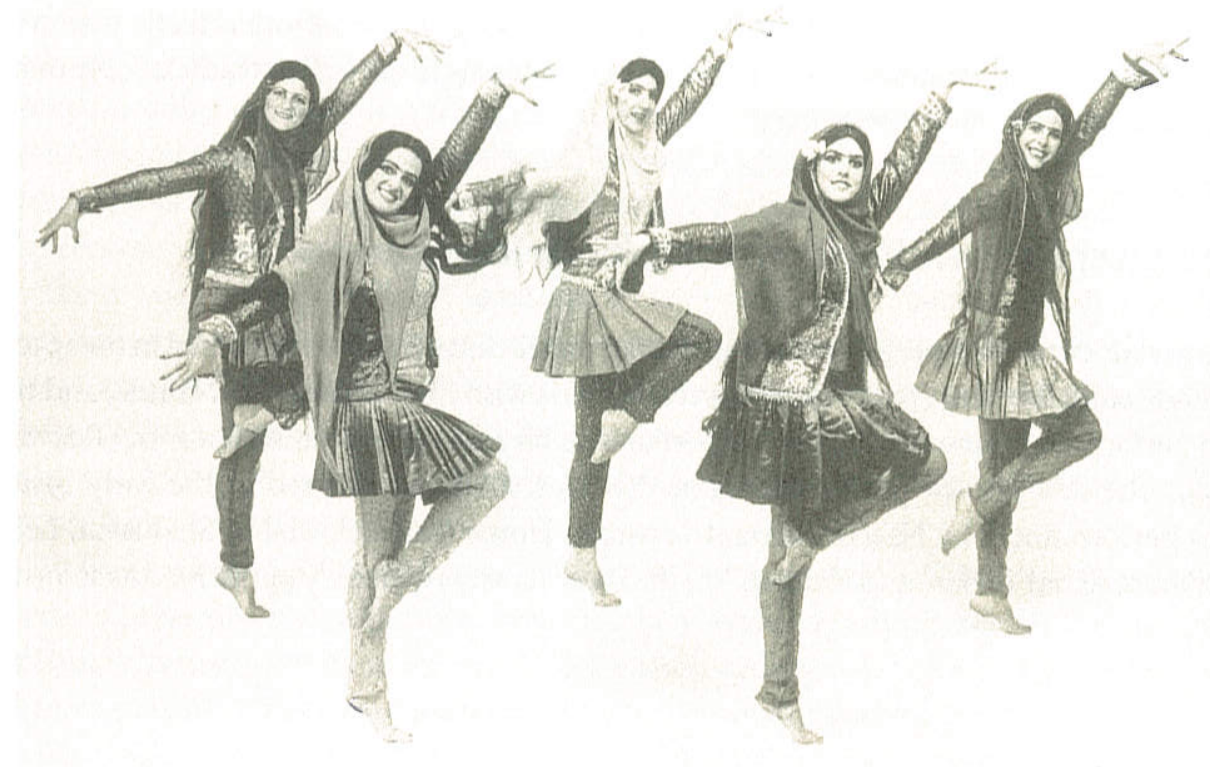

FIGURE 28.2 Qajar dance. Choreographed by Ixchel Diemetral-Maerker. Photo by Darren Young, Los Angeles, 1978. Courtesy of the AVAZ International Dance Theatre.

choreographers and dancers outside of Iran utilized this same combination of Westernized ballet and Iranian character or "national" dance begun in the 1930s in Iran. Several untrained Iranian students simply elaborated the solo improvised dance that they had learned at social gatherings, dressing up in fantasy costumes that owed more to Hollywood than to Iranian history to lend their performances an exotic aura. Later, after the formation of the diaspora in 1980, new styles evolved in which social dances such as hip hop and salsa were added to the already eclectic mix (see Figure 28.2).

The Iranian dancers and choreographers who left Iran after the 1979 Revolution found several non-Iranians already at work. Sometimes they cooperated and performed together; at other times, they found themselves in competition. The early performances from the 1930 seatured Iranian character dance. This revival dance genre from the 1930 s remains among the most popular genres in the diaspora down to the present day. Beginning in the late 1950s, choreographers in Iran who worked with the government-sponsored companies and non-Iranians in the United States began using choreographic strategies based on the state folk dance ensemble model, using, for the 
first time, large numbers of musicians and dancers. In a final phase, during the late 1990s, we see some bold Iranian artists, like Jamal, Banafsheh Sayyad, Ida Meftahi, and Sashar Zarif, begin to create serious works of art, using an even more eclectic fusion of elements that include modern dance, flamenco, and tai-chi, as well as traditional Iranian themes and movement vocabulary.

\section{The First Known Performances Outside Iran}

The first documented performances of Iranian dance outside of Iran occurred in the 1930s, when Medjid Rezvani (1900-1962) moved to Paris with his Iranian wife, Nahide, and the two performed frequently in Paris and other French cities (Décoret-Ahiha 2004; Rezvani 1962). The first known performances in the United States occurred in the early 1950s, with performances by Nasrin Hekmat Forough, Homa Mojallal, Mahin Shahrivar, Leila Bedalian, Assad Torfeh, and Najmeh Najafi. These dancers generally performed as soloists.

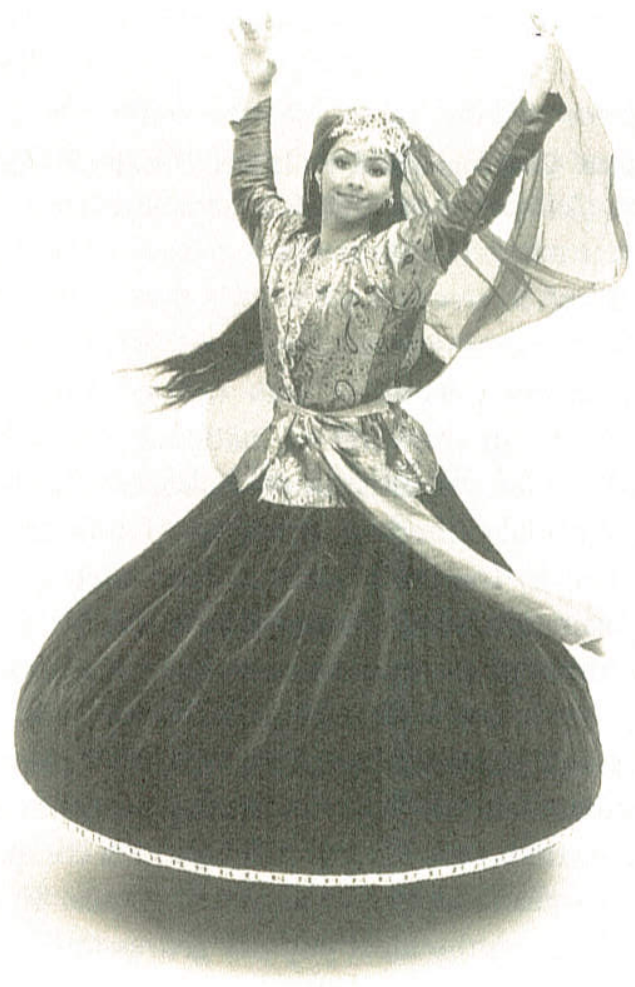

FIGURE 28.3 Classical Persian dance. Soloist Lynette Houston. Choreographed by Jamal. Photo by Darren Young, Los Angeles, 1996. Courtesy of the AVAZ International Dance Theatre. 
Nasrin Hekmat Forough occasionally trained small groups, often relying on non-Iranians because of the reluctance of Iranians, especially men, to perform in public. I learned and performed my first dances from Hekmat Forough in 1954. Large repertory ensembles only came into existence in the 1960 s, following the first appearance of Eastern European companies like the Moiseyev Dance Company in the late 1950s, and these were almost all founded and directed by Anglo-Americans. No attempt to create revivalist versions of regional folk dances for the stage occurred before the late 1960s, and choreographers and dancers exclusively used stage versions of solo improvised dance (see Figure 28.3).

The music that was available for dance in the period before 1980 was extremely limited. Although a few students were able to play dance music on violins, tars (long-necked lutes), santurs (hammered dulcimers), accordions, and tombaks (goblet drums) for special occasions, most performances were accompanied by classical rengs (dance melodies) and folk tunes played by small urban orchestras on delicate $78 \mathrm{rpm}$ records. These recordings were few in number.

In Iran and in the diaspora, poetry is the most important and beloved form of cultural expression. Its ubiquitous presence in a wide variety of social, political, and spiritual contexts attests to its popularity, even if its linguistic specificity limits its usefulness outside of Persian-speaking contexts. However, Iranians coming abroad as students quickly grasped that dance constituted one of the most popular representational forms of culture in the West and that it was more accessible to the general public than musical or verbal forms of expression. This was especially true in the United States, where several events caused folk and traditional dance performances to become enormously popular. Beginning in the late 1920s, cities and towns across America began to host large-scale annual international folk dance concerts and festivals (Shay 2006). Colleges and universities, which-especially after World War II-had large numbers of foreign students, also provided many concert opportunities. Later, ethnomusicology departments offered numerous music and dance performances. In addition, the international recreational folk dance movement that had begun in the 1930 s expanded significantly in the 1950 s and 1960s; the hundreds of thousands of individuals who now participated in this movement provided large audiences for international folk dance performances. In the late 1950s, following the appearances of professional state folk ensembles from Yugoslavia and the Moiseyev Company of the Soviet Union, professional and amateur performances of folk dance became more popular than ever (Shay 2002a, 2006, 2008a). It was during this period in Iran and the United States that attempts were made to stage regional folk dances that had remained largely unknown to urban dancers prior to this period, thus bringing to life Guss's notion of "cultural objectification."

\section{Autoexoticism}

Beginning with Medjid Rezvani and Najmeh Najafi, Iranians quickly understood that coming from Persia carried the cachet of the romantically exotic, and they began to spin 
pungently spiced exotic tales about solo improvised dance that appealed to the orientalist fantasies held by many Westerners. Najmeh Najafi, for example, wrote:

Many of our dances tell stories: some are survivals from a very ancient time, like the Zoroastrian Dance of Fire. Some came from the Islamic influence. At first I used to dance just as I felt; but later I learned the traditional dances, blending my emotion with the emotion of the dance story. In our dancing the movement of the hands tells special things. There is a language of motion, and people who know this language can interpret the story as well as if it were in spoken words. People in America who have seen me dance say, "Your hands are so graceful!" Hands must be graceful in order to be talking hands....

Maybe one of our traditional dances will explain this. It is the story of a dancer who was loved by a prince. He could not marry her because she was a dancer, so she went away with a broken heart. Without her he could not be happy so he found her and told her that he would give up being a prince in order to marry her. If there were a choice between the kingdom and her, he had made that choice. But she knew that he must be a prince and later a king for the good of his people, so she told him that her broken heart had been healed by another and that she no longer loved him.

(Najafi 1953: 28-29)

Najafi's colorful and meretricious account of Iranian dance had perhaps been inspired by examples of Indian classical dance forms, such as the bharata natyam or kathak, which do utilize narrative hand movements. However, Iranian dance is not a narrative art form but an abstract one. There is no form of codified movement such as that found in bharata natyam. Iranian dancers created these orientalist tales to make their performances more appealing. Thus, we can see in this example and in the earlier descriptions of Ramazani's performances that Said's notion of orientalism constitutes a persistent feature of many of these revival dance performances.

Rezvani's book on Iranian dance (1962) is likewise filled with a fantasy history and descriptions of a nonexistent, pre-Islamic classical dance tradition that he claimed was guarded in secret by certain families throughout the Islamic period. He and his wife are depicted in this book and other sources, romantically costumed as "villagers" or dressed as pre-Islamic historical figures (Décoret-Ahiha 2004; Rezvani 1962).

Individuals who claim to utilize Persian miniatures as the basis of their dances have developed another form of exoticism and autoexoticism. Robert De Warren, the English former director of Mahalli Dancers, stated in a printed program:

Collection of his [the poet Nezami's] works... also contain a rich tapestry of miniatures...the representation of the dance is very evident, the Safavid [1501-1725] versions being the richest in movement and style. Not only has it been possible to trace actual dance movements, but also musical and percussion instruments that have long been lost.... Each step and gesture is a reproduction of the real traditional painting. Choreographed after almost two years of research.

(Program of the Mahalli Dancers of Iran, 1976) 
In an interview, De Warren stated that he was able to lay "twenty or so of them [Persian miniatures] side by side" to recreate an authentic production of dances performed during the Safavid period (1501-1722) (1973: 29). (For the problems of using historical visual art as a source for dance reconstruction see Lawler 1964.). This kind of autoexoticism and exoticism continues unabated in many performances, and Americans and other non-Iranians continue to make their performances more interesting to geographically challenged Americans by giving them orientalist flavorings from The Thousand and One Nights, as mediated through the lens of Hollywood.

Some Americans and other non-Iranians who participate in the world of Iranian dance, especially those who came to it through the performance of belly dance, are often as prone to exoticism as the early Iranian dancers and choreographers, as Cram Cook's choreographic plots and De Warren's quotation demonstrate.

\section{The State Folk Dance Ensemble Model}

In the 1950s, the Moiseyev Dance Company from the Soviet Union and other state-supported dance ensembles from Eastern Europe created a revolution in the presentation of folk dance as a field of representation for ethnic identity and diversity. Nation-states as politically diverse as the Philippines, Greece, Venezuela, Mexico, Iran, Egypt, and Ghana scrambled to follow the example set by Igor Moiseyev (Shay 2002a).

Iranian dance was almost exclusively performed solo, both traditionally and in the early ballet dance performances in Iran. Each of the dancers in the new ballet productions had his or her role, and there is little description of dances performed as ensemble productions using synchronized choreographies. The early dancers I encountered in the diaspora, such as Nasrin Hekmat Forough, Mahin Shahrivar, Leila Bedalian, and Homa Mojallal, all danced solos that were largely improvised and used costumes exhibiting various degrees of orientalism.

The appearances of the Moiseyev Dance Company, Kolo, the Serbian State Folk Dance Ensemble, Tanec, the Macedonian State Ensemble, and later LADO, the Croatian State Folk Ensemble, altered that trend and provided choreographers like myself with a new vision of how dance could be presented in a more spectacularized fashion. In 1960, I founded the UCLA Village Dance Group, and, in 1963, I changed the name to the AMAN Folk Ensemble. I began choreographing Iranian dances for the stage using the types of choreographic strategies that I saw in performances by the Eastern European companies, rather than those used by Iranian companies. (See Web Figure 28.1 for a photograph from my choreographed piece "Savaran." (2)

Americans involved in Iranian dance differed from Iranians in two significant ways. First, we did not feel compelled to confine our interest to the nation-state of Iran and its contemporary borders. I found examples of Uzbek classical dance on films that the Soviet Embassy, and later the Committee for Friendship and Cultural Relations with Foreign Countries, generously provided me. I found an interest in the vibrant dances of the ancient Iranian cities of Bukhara and Samarqand, renowned in Persian poetry, that my Iranian colleagues never did. From 1960, together with my co-artistic director 
in AMAN, Leona Wood, I produced many choreographies from Iran, as well as from surrounding areas such as Armenia, Azerbaijan, Georgia, Uzbekistan, and Tajikistan. I continued this work with the AVAZ International Dance Theater, which has boasted a large Iranian-Central Asian repertoire into the twenty-first century. In 1990, Jamal joined AVAZ and in 1995 became its sole director. (See Figure 28.4 for a photograph from an Azerbaijani dance that I choreographed, and see Web Figure 28.2 for a photograph from my choreographed version of a piece from Samarqand. (-)

The second way in which Americans differed from Iranians was the Americans' intense interest in authenticity. This resulted in many American choreographers conducting research through field work; taking classes with experts; attending events, concerts, and festivals in which dancing took place; and acquiring books, films, and other documentation. Many learned the requisite languages for conducting fieldwork. In general, their choreographic works were informed by this intensive research.

Although in the late 1950 and throughout the 1960 s the academic concept of appropriation had not yet appeared in the world of folk dance, American choreographers nevertheless felt the need for accuracy and authenticity to show respect for the people whose culture they were representing in public venues, even while creating works that were theatrically arresting.

In the 1960 s and 1970s, Americans-in contrast to most post-Revolution Iranian and European performers-founded very large ensembles, frequently numbering sixty to eighty performers. This serendipitously coincided with the search for ethnic heritage and "roots" that was one of the most important characteristics of that period. Other Americans who joined the counterculture had deep feelings of anomie toward the consumerist, middle-class values and political conservatism that characterized the period following World War II. Becoming Balkan or Middle Eastern peasants, garbed in colorful costumes, answered their search for experiences that would give meaning to their lives. This meant that large numbers of talented college and university students, as well as members of the international recreational folk dance movement, were eager to devote the many hours of rehearsal required to perform at a professional level the Balkan and Middle Eastern dance genres they had recently discovered (Shay 2008a, 2008c). These ensembles, many of which lasted for decades, created new repertoires and often toured widely.

During this period, following the strategies of the national companies, choreographers like myself produced large-scale productions, often featuring dozens of dancers accompanied by live orchestras. Simple folk dances were combined into suites, the time frames of the dances were compressed, and improvised dancing was synchronized and formed into organized choreographies. In the 1990s, these large companies either closed or faded into smaller ensembles because the social basis that permitted the formation of these large ensembles that characterized the 1960 s and 1970 s disappeared. Americans and Europeans became attracted to disco and other dance genres, and the recreational folk dance movement contracted.

In the Iranian diaspora, however, many smaller dance companies continued to grow and proliferate. These companies have become an important vehicle for those in the 


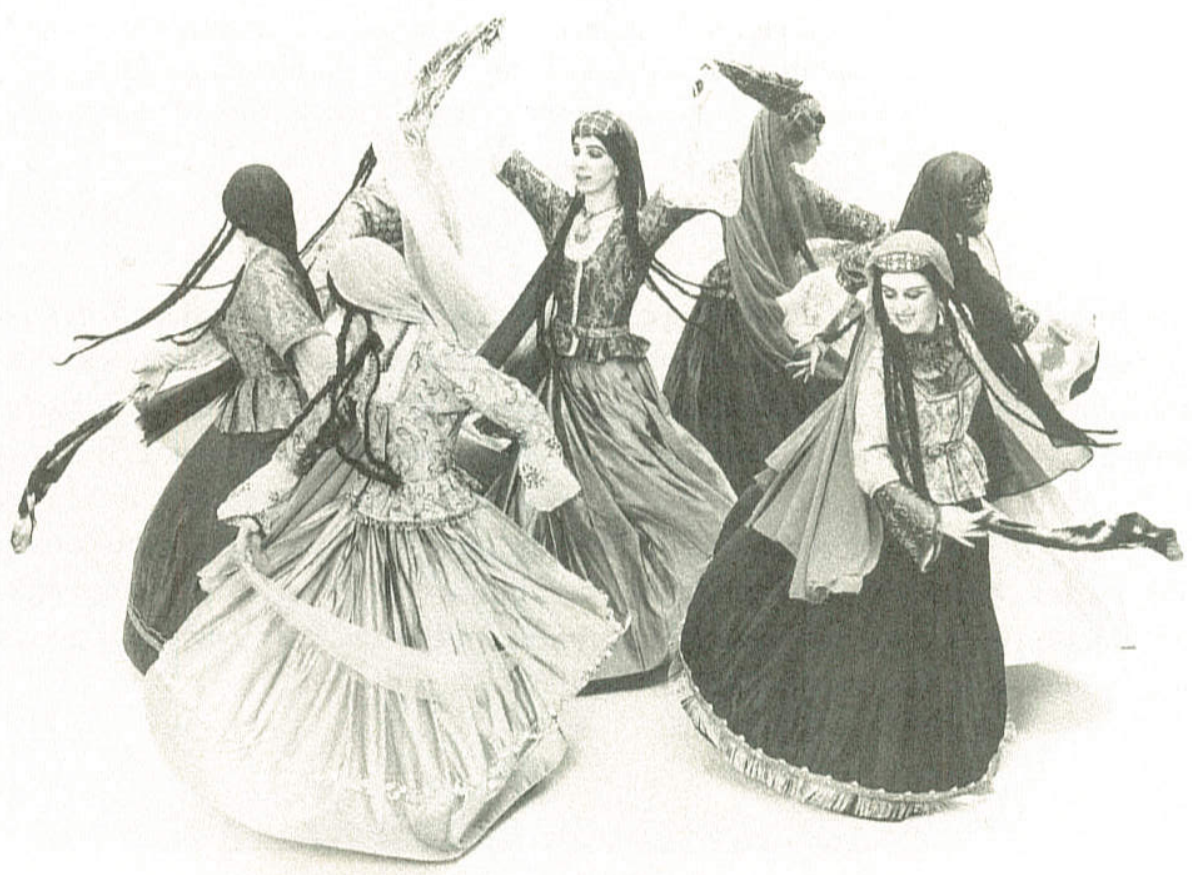

FIGURE 28.4 "Dasmali" Azerbaijani dance. Choreographed by Anthony Shay. Photo by Darren Young, Los Angeles, 1980. Courtesy of the AVAZ International Dance Theatre.

diaspora to create representational fields for their identity, particularly since dance is banned in Iran-and this provides an added urgency for young Iranian Americans to perform. In contrast to the American concern for authenticity, many Iranian choreographers and dancers-especially those who came after the Revolution-felt that because they were of the heritage, they already knew enough to create works based on their varied knowledge. As one informant told me, "I dance Persian dance perfectly because it's in my blood" (quoted in Shay 1999: 20). These dance companies were overwhelmingly smaller than those of their American counterparts.

In addition, the Iranians-especially those like Abdollah Nazemi, who had directed and choreographed work in Iran-found an entirely new environment in the U.S. diaspora community. First, Iranians of the diaspora overwhelmingly sought entertainment rather than art. They wanted dancers to entertain at weddings and parties. The entire popular music industry of Iran moved to the Los Angeles area and quickly began to make videos in which dance became an important background element. Since most Iranians were reluctant to perform publicly, they found American dancers who could be trained by the few Iranians who eagerly sought work in this new environment. Communications scholar Hamid Naficy described the result of using American dancers: 
Recent sexist videos by male Iranian singers feature white leggy dark-haired Anglo female dancers who try to pass as Iranian, using their physical similarity to Iranian women as well as imitations of the Iranian dancing style. If the former qualities favor their inscription as Iranian women, the inexactness and exaggeration of their imitations give away their "inauthenticity."

(Naficy 1993: 180)

As in Iran, the dancers and choreographers, both Iranian and non-Iranian, divided into two separate spheres: the artists who appeared in theaters and concert settings, and the entertainers, in the manner of Mohammad Khordadian, who carried on the motreb tradition of southern Tehran by appearing in weddings, cabarets, and videos. The former, like the AVAZ International Dance Theater, are generally sought to represent the Iranian community in formal settings, particularly to the outside world, whereas the latter provide sources of entertainment within the community. More recently, Iranian student groups have formed across the United States on college and university campuses, and these groups eagerly post their work on YouTube.

\section{The New Vision}

In the 1990s, non-Iranians and some Iranians alike continued to follow the state folk dance model, aided by the availability of video recordings of former Iranian state-supported dance ensembles, whose choreographies they often copied. Several Iranians of the diaspora who began to encounter new dance genres, such as jazz and modern dance, experimented with fusion and hybrid forms of their own creation. Many of them turned to historical, spiritual, and poetic sources, and the work they produced varied widely.

Since the works of the mystic poet Jallal-ad-Din Rumi have become popular in the West, Sufism serves as a source of inspiration for several choreographers like Jamal, the artistic director of the AVAZ International Dance Theater; Nima Kiann, artistic director of the Ballets Persans; and soloists Banafsheh Sayyad, Shahrokh Meshkinghalam, and Sashar Zarif.

In this final section, I analyze the work of Jamal, since I am most familiar with his choreographic output. After having choreographed a large repertoire of regional folk dances and solo improvised dance, he declared:

I do not want to carry any more baskets and scarves on the stage. I want to create work that is more contemporary. I am an artist of the twenty-first century and I do not wish to be depicted as a primitive man at the dawn of time wearing a robe and beating on a frame drum. 


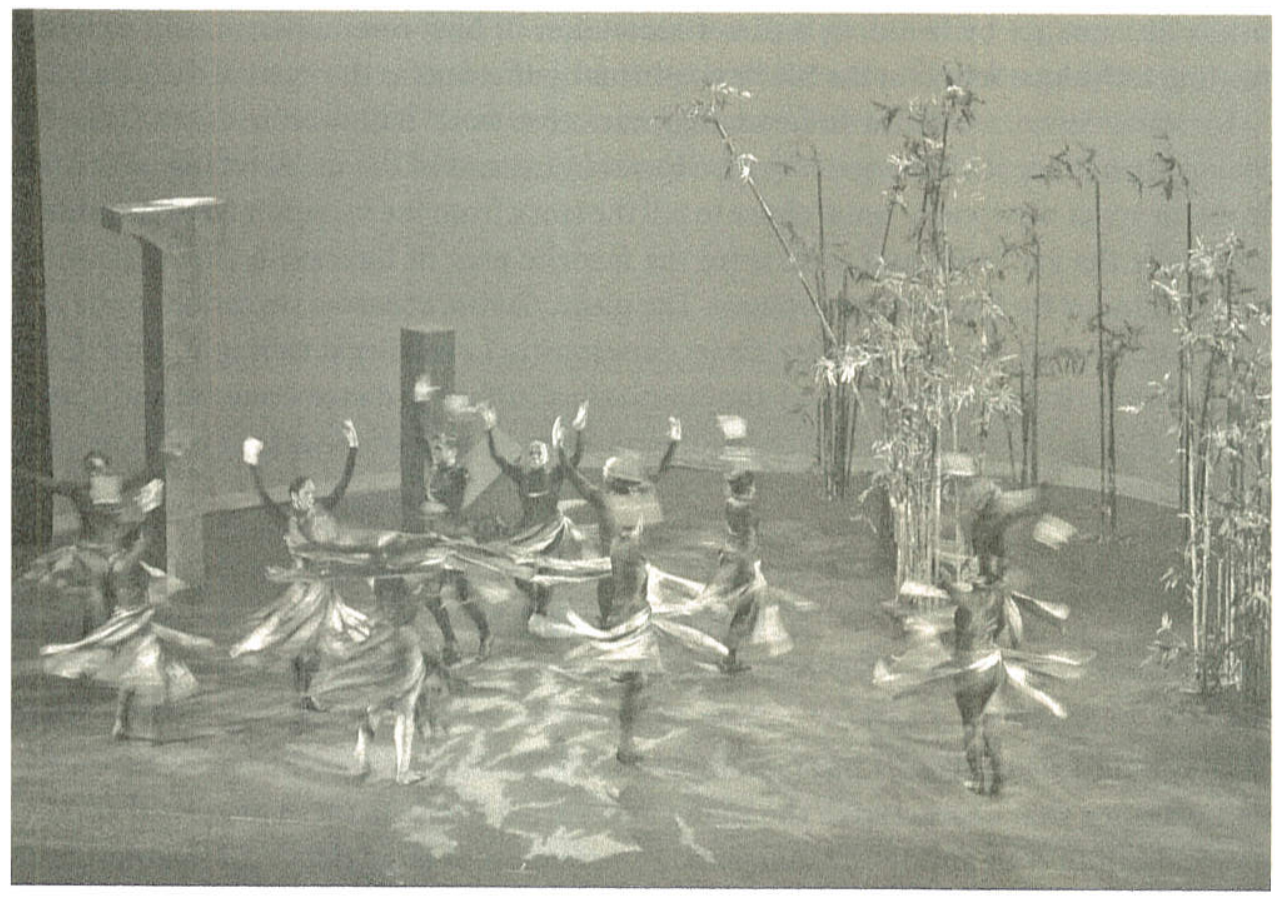

FIGURE 28.5 Guran, choreographed by Jamal. Photo by Sallie D’Ette Mackie, Luckman Auditorium, California State University Los Angeles, 2003. Courtesy of the AVAZ International Dance Theatre.

He began to add new and different works to the group's repertoire. His first work to constitute a departure was a choreography of Shateri in 1994, an earthy solo improvised dance traditionally performed by working-class men in South Tehran. Jamal, for the first time, refashioned the dance for a large group, mostly female, performing in unison. The Iranians of the diaspora loved this piece, and it has been widely emulated by college and university student groups. (See Web Figure 28.3 for a photograph of Shateri choreographed by Jamal 우.)

The next year, he created Soug, an impressionistic piece based on the unusual practice found in some regions of the Iranian province of Luristan in which people dance at funerals. He later enlarged this piece as an outdoor work to commemorate the events of September 11, 2001. This time, dozens of performers from several Los Angeles dance companies participated; the performance was staged in an open air plaza and drew hundreds of onlookers. Other dance companies around the United States performed the work precisely at noon on September 11, 2012, a year after the horrific terrorist attack on the Trade Towers of New York City

Next, he created Charkh (Turning), inspired by the spiritual character of Sufism and the universal message of Rumi's inspirational work. However, he chose to avoid creating 
orientalist images by avoiding a direct recreation of Sufi ceremonies, using only the turning technique found in the Mevlevi spiritual gatherings as the basis of the piece.

In 2004, Jamal created a full-evening, narrative work based on a scene from the Shahnameh, the epic history of Persia. However, instead of the usual telling of the tale from the royal viewpoint, Jamal chose to tell the story from the viewpoint of the animals, especially the gur (wild ass), who were the favorite prey of Bahram-e Gur, a Sasanian prince famous for his hunting prowess. The piece, Guran, caused a sensation in the arts community, with the Los Angeles Times dance critic Lewis Segal calling it "one of the most distinctive achievements of the Southern California dance community" (Segal 2005 : $\mathrm{E}_{3}$ ). (See Figure 28.5 and Web Figures 28.4 and 28.5 for photographs of Guran choreographed by Jamal $:$.)

\section{Conclusion}

Throughout this chapter, I have attempted to demonstrate my concept of the parallel traditions that characterize the many and varied performances of revival Iranian dance, both in Iran and in the diaspora. The creation of large dance companies, both in Iran and abroad, characterized by large, spectacular choreographies and costume displays based on a dance tradition created in the 1930 s and continuing into the twenty-first century, reflect Guss's notion of "cultural objectification." The Iranian government's use of these dance companies to foster a positive Iranian identity among its citizens underscores Desmond's observation that dance is "constitutive of identity." The content of many of these performances brings to life the fantasy images that Said utilized in his idea of orientalism. The concept of "choreophobia" that I developed around Iranian attitudes toward dance generally clashed with the Iranian government's attempts to utilize orientalist choreographic works to create a positive and romantic image of the Iranian state that paradoxically created a space of resistance to the regime.

Thus, dance, in less than a century, has moved from solo performances of socially disreputable public performers, tribal celebrations, or sexually segregated private performances, to become a multilayered phenomenon that engages Iranians and non-Iranians alike. The use of dance in Iran constituted a governmental attempt to build pan-Iranian national identity at home and to use it as a vehicle for displaying Iranian culture through performing folk dance companies. In the Iranian diaspora, dance began as a means of displaying Iranian identity on American university campus events and festivals, and, more recently, it has constituted a vehicle for the Iranian community to display itself in holiday attire. Revival dance has grown increasingly complex on many levels-as art, as representation, and as celebration.

Iranians of the diaspora increasingly attend dance concerts and send their children to dance classes as a way of affirming their Iranian identity. Thus, after an initial 
reluctance to use dance as a field of representation for Iranian identity, Iranians of the diaspora increasingly turn to dance in a variety of formats to create positive images of Iranian national identity. Both in Iran, where dance constitutes a vehicle for resistance, and in the diaspora, dance has increasingly become the sought after, not the reluctant art.

\section{Note}

1. For video examples, search on www.youtube.com with the keywords "dance" and "Iran" (or "Azerbaijan") followed by the name of a region or ethnocultural group (e.g., Gilan, Mazanderan, Zabol, Kurdish).

\section{REFERENCES}

Ameri, Azardokht. 2003. "Raqs-e amiyaneh-ye shahri va raqs-e mowsum be klasik-e Irani: barresi-ye tatbiqi dar howze-ye Tehran.” Mahoor Music Quarterly 2 (Summer): 51-74.

Beiza'i, Bahram. 1965. Namayesh dar Iran. Tehran: Kaivan Press.

Buckland, Theresa J.1999. Dance in the Field: Theory, Methods and Issues in Dance Ethnography. New York: St. Martins Press.

Décoret-Ahiha, Anne. 2004. Les danses exotiques en France: 1880-1940. Pantin, France: Centre national de la danse.

Desmond, Jane C. 1997. "Introduction." In Meaning in Motion: New Cultural Studies of Dance, edited by Jane C. Desmond, 1-25. Durham, NC: Duke University Press.

De Warren, Robert and Peter Williams. 1973. "Discovery in Persia." Dance and Dancers. January, 23: $28-32$.

Diba, Layla S., and Maryam Ekhtiar. 1998. Royal Persian Paintings: The Qajar Epoch, 1785-1925. New York: Brooklyn Museum of Art.

'Enjavi-Shirazi, M. A. 1972. Bazi-ha-ye namayeshi. Tehran: Amir Kabir.

Falk, S. J. 1972. Qajar Painting. London: Sotheby.

Fatemi, Sasan. 2005. "La Musique Legere Urbaine dans La Culture Iranienne: Reflexions sur les notions de classique et populaire." Ph.D. dissertation, Universite Paris X-Nanterre, Paris.

Georges, RobertA., and MichaelJones.1995.Folkloristics:AnIntroduction.Bloomington:Indiana University Press.

Gore, Georgiana, and Maria Koutsouba. 1992. “'Airport Art' in a Sociopolitical Perspective: The Case of the Greek Dance Groups of Plaka.” Proceedings. 17th Symposium of the Study Group on Ethnochoreology. Nafplion, Greece, July 2-10: 29-34.

Guss, David M. 2000. The Festive State: Race, Ethnicity, and Nationalism as Cultural Performance. Berkeley: University of California Press.

Hamada, Geoffrey Mark. 1978. "Dance and Islam: The Bojnurdi Kurds of Northeastern Iran." Unpublished master's thesis, University of California, Los Angeles.

Handler, Richard. 1988. Nationalism and the Politics of Culture in Quebec. Madison: University of Wisconsin Press.

Hasanov, Kamal. 1988. Azarbaijan Gadim Folklor Ragslari. Baku: Ishig. 
Hill, Derek, and Oleg Grabar. 1964. Islamic Architecture and Decoration. Chicago: University of Chicago Press.

Hobsbawm, Eric and Terence Ranger, eds. 1983. The Invention of Tradition. Cambridge: Cambridge University Press.

Jackson, Bruce. 1993. "The Folksong Revival." In Transforming Tradition: Folk Music Revivals Examined, edited by Neil V. Rosenberg, 73-83. Urbana: University of Illinois Press.

Kiann, Nima. 2000. "Persian Dance and its Forgotten History." http://artira.com/nimakiann/ history/history.htm, accessed July 28, 2012.

Kirshenblatt-Gimblett, Barbara. 1991. "Objects of Ethnography." In Exhibiting Cultures: The Poetics and Politics of Museum Display, edited by Ivan Karp and Steven D. Lavine, 386-443. Washington, DC: Smithsonian Institution Press.

Kirshenblatt-Gimblett, Barbara. 1994. “On Difference." Journal of American Folklore 107 (424): 235-238.

Lawler, Lillian. 1964. Dance in Ancient Greece. Middletown, CT: Wesleyan University Press.

Mahdavi, Pardis. 2009. Passionate Uprisings: Iran's Sexual Revolution. Stanford, CA: Stanford University Press.

Meftahi, Ida. 2007. "Re-thinking the History of Dance in the 2oth Century Iran: Nationalizing Dance to Exhibit Iranian Identity." Proceedings. Society of Dance History Scholars International Conference, 149-152.

Naficy, Hamid. 1993. The Making of Exile Cultures: Iranian Television in Los Angeles. Minneapolis: University of Minnesota Press.

Najafi, Najmeh. 1953. Persia is My Heart. New York: Harper.

Necipoglu, Gülru. 1995. The Topkapi Scroll-Geometry and Ornament in Islamic Architecture. Santa Monica, CA: Getty Center for the History of Art and the Humanities.

Pope, Arthur Upham, ed 1964-1965a. "Introduction." In A Survey of Persian Art, vol. 1, edited by Arthur Upham Pope et al., 1-41. Oxford: Oxford University Press.

Pope, Arthur Upham. 1964-1965b. "Calligraphy: an Outline History." In A Survey of Persian Art, vol. 4, edited by Arthur Upham Pope et al., 1707-1742. Oxford: Oxford University Press.

Ramazani, Nesta. 2002. The Dance of the Rose and the Nightingale. Syracuse, NY: Syracuse University Press.

Rezvani, Medjid. 1962. Le theatre et la danse en Iran. Paris: Maisonneuve et Larose.

Rosenberg, Neil V., ed. 1993. Transforming Tradition: Folk Music Revivals Examined. Urbana: University of Illinois Press.

Said, Edward. 1978. Orientalism. New York: Vintage Books.

Segal, Lewis. 2005. 'AVAZ Troupe Shows its Stripes with Revised 'Guran.' Los Angeles Times. April 19: E3.

Shay, Anthony. 1995a. "Dance and Non-Dance: Patterned Movement in Iran and Islam." Iranian Studies 28 (1-2): 61-78.

Shay, Anthony. 1995b. "Bazi-ha-ye namayeshi: Iranian Women's Theatrical Plays." Dance Research Journal 27 (2): 16-24.

Shay, Anthony. 1997. "In Search of Traces: Linkages of Dance and Visual and Performative Expression in the Iranian World." Visual Anthropology 10: 335-360.

Shay, Anthony. 1999. Choreophobia: Solo Improvised Dance in the Iranian World. Costa Mesa, CA: Mazda Publishers.

Shay, Anthony. 2002a. Choreographic Politics: State Folk Dance Companies, Representation and Power. Middletown, CT: Wesleyan University Press. 
Shay, Anthony. 2002b. "Dance in Iran." In The Garland Encyclopedia of World Music, Volume 6: The Middle East, edited by Virginia Danielson, Scott Marcus, and Dwight Reynolds, 875879. New York: Routledge.

Shay, Anthony. 2006. Choreographing Identities: Folk Dance, Ethnicity, and Festival in the United States and Canada. Jefferson, NC: McFarland.

Shay, Anthony. 2008a. Dancing Across Borders: The American Fascination with Exotic Dance Forms. Jefferson, NC: McFarland.

Shay, Anthony. 2008b. "Dance and Human Rights in the Middle East, North Africa, and Central Asia." In Dance, Human Rights, and Social Justice: Dignity in Motion, edited by Naomi Jackson and Toni Shapiro-Phim, 67-85. Lanham, MD: Scarecrow Press.

Shay, Anthony. 2008c. "Introduction." In Balkan Dance: Essays on Characteristics, Performance and Teaching, edited by Anthony Shay, 12-33. Jefferson, NC: McFarland.

Shay, Anthony, and Barbara Sellers-Young. 2005. Belly Dance: Orientalism, Transnationalism, and Harem Fantasy. Costa Mesa, CA: Mazda Publishers.

Al-Saltana, Taj. 1993. Crowning Anguish: Memoirs of a Persian Princess from the Harem to Modernity, edited with Introduction \& Notes by Abbas Amanat, translated by Anna Vanzan, and Ali Neshati. Washington, DC: Mage.

Titon, Jeff Todd. 1992. "Reconstructing the Blues: Reflections on the 1960s Blues Revival." In Transforming Tradition: Folk Music Revivals Examined, edited by Neil V. Rosenberg, 220240. Urbana: University of Illinois Press. 